\title{
Penerapan Metode RAD dalam Merancang Aplikasi Web Proyek PLN UIP Sulbagut
}

\author{
Cleorangga Mandang ${ }^{1}$, David C J. Wuisan ${ }^{2}$, Jeener G L. Mandagi ${ }^{3}$ \\ 1 Program Studi Teknik Informatika UNIMA; 2 Program Studi Teknik Informatika UNIMA; 3 Program Studi Teknik Informatika UNIMA \\ Email:17210061@unima.ac.id
}

\begin{abstract}
PLN UIP Sulbagut is a company unit in the sector of electricity construction, this unit carries out the construction control and management of the construction of Generators, Transmissions and Substations. The design of the PLN UIP Sulbagut Project Web Application is a solution in helping the public to know about PLN UIP Sulbagut and its construction projects. The results and discussion here shows the Web Application of the PLN UIP Sulbagut is a media that makes it easy for the public to know about this work unit. This application was developed based on the Rapid Application Development (RAD) model which is one of the systems development methods and is modeled with object-oriented modeling tools that are compatible with the RAD model, the Unified Modeling Language (UML).
\end{abstract}

Keywords - Web Application, Rapid Application Development, Unified Modelling Language

\begin{abstract}
Abstrak - PLN UIP Sulbagut merupakan unit perusahaan bidang konstruksi ketenagalistrikan, unit ini melakukan pengendalian konstruksi dan pengelolaan pembangunan Pembangkit, Transmisi dan Gardu Induk. Perancangan Aplikasi Web Proyek PLN UIP Sulbagut merupakan satu solusi dalam membantu masyarakat mengetahui tentang PLN UIP Sulbagut serta proyek-proyek konstruksinya. Hasil dan pembahasan disini memperlihatkan Aplikasi Web Proyek PLN UIP Sulbagut menjadi media yang memudahkan masyarakat mengetahui tentang unit kerja ini. Aplikasi ini dikembangkan atas dasar model Rapid Application Development (RAD) yang merupakan salah satu metode pengembangan sistem dan dimodelkan dengan tools pemodelan berorientasi objek yang cocok dengan model RAD yaitu Unified Modelling Language (UML).
\end{abstract}

Kata Kunci- Aplikasi Web, Rapid Application Development, Unified Modelling Language.

\section{Pendahuluan}

PLN UIP SULBAGUT merupakan unit perusahaanyang bergerak di bidang proyek ketenagalistrikan yang terintegrasi di wilayah provinsi suluttenggo. PLN UIP SULBAGUT didirikan berdasarkan Peraturan Direksi dan secara operasional telah aktif sejak tanggal 27 Juni 2016. Sesuai dengan Peraturan Direksi Nomor 0017.P/DIR/2016 tentang organisasi PT PLN (Persero) Unit Induk Pembangunan Sulawesi Bagian Utara, Direksi PT PLN (Persero) menugaskan PT PLN (Persero) Unit Induk Pembangunan Sulawesi Bagian Utara untuk melakukan pengendalian konstruksi dan pengelolaan kegiatan pembangunan pembangkit dan jaringan. Peraturan Direksi ini dibuat dalam rangka untuk menegaskan fungsi dan wilayah kerja unit yang mengelola kegiatan pembangunan pembangkit dan jaringan di wilayah Sulawesi Utara, Gorontalo, dan Sulawesi Tengah serta guna meningkatkan efektivitas pelaksanaan organisasi Direktorat Bisnis Regional Sulawesi.

Dalam operasional pengawasan pelaksanaan pekerjaan konstruksi PLN UIP SULBAGUT mempunyai data proyek UPP Pembangkit dan Jaringan (berdasarkan RUPTL 20192028) yang disahkan oleh Menteri ESDM yaitu UPP Pembangkit dan Jaringan Sulawesi Utara yang berkedudukan di Manado, UPP Pembangkit dan Jaringan Sulawesi Tengah yang berkedudukan di Palu dan UPP
Pembangkit dan Jaringan Gorontalo yang berkedudukan di Gorontalo. Aplikasi web adalah satu sarana yang efektif untuk memperkenalkan kepada masyarakat mengenai informasi tentang PLN UIP Sulbagut terkait dengan pekeerjaan atau proyek-proyek konstruksi yang dilakukan.

\section{LANDASAN TEORI}

\section{A. Aplikasi Web}

Aplikasi berbasis web merupakan sebuah aplikasi yang dapat diakses dengan jaringan internet atau intranet melalui mesin pencari (browser). Aplikasi web juga merupakan sebuah perangkat lunak atau software yang di dibangun dengan dasar bahasa pemogramman seperti html, javascript, css, php, dan bahasa pemogramman lainnya[2]. Salah satu kelebihannya aplikasi web juga dapat diakses melalui berbagai platform dan informasi disajikan oleh web browser pada sistem operasi mana saja. Aplikasi berbasis web dapat digunakan untuk berbagai macam tujuan atau kepentingan yang berbeda.

\section{B. Rapid Application Development (RAD)}

Rapid Application Development (RAD) yaitu suatu pendekatan berorientasi objek terhadap pengembangan sistem yang mencakup suatu metode pengembangan serta perangkat-perangkat lunak (Kendall dan Kendall, 2002). Rapid Application Development (RAD) adalah strategi siklus hidup yang ditujukan untuk menyediakan 
pengembangan yang jauh lebih cepat dan mendapatkan hasil dengan kualitas yang lebih baik dibandingkan dengan hasil yang dicapai melalui siklus tradisional (McLeod, 2002). Dari definisi-definisi RAD tersebut, dapat dilihat bahwa pengembangan aplikasi menggunakan metode RAD ini dapat dilakukan dalam waktu yang relatif cepat karena pada saat Rapid Application Development (RAD) diimplementasikan, maka para pemakai bisa menjadi bagian dari keseluruhan proses pengembangan sistem dengan bertindak sebagai pengambil keputusan pada setiap tahapan pengembangan. RAD bisa menghasilkan suatu sistem dengan cepat karena sistem yang dikembangkan dapat memenuhi keinginan dari para pemakai sehingga dapat mengurangi waktu untuk pengembangan ulang setelah tahap implementasi.

Menurut Kendall \& Kendall (2002), terdapat tiga fase dalam RAD yang melibatkan penganalisis dan pengguna dalam tahap penilaian, perancangan, dan penerapan. Adapun ketiga fase tersebut adalah requirements planning (perencanaan syarat-syarat), RAD design workshop (workshop desain RAD), dan implementation (implementasi). Sesuai dengan metodologi RAD menurut Kendall, berikut ini adalah tahapan pengembangan aplikasi dari tiap fase RAD.

1) Requirements Planning: Dalam fase ini, pengguna dan penganalisis bertemu untuk mengidentifikasikan tujuan-tujuan aplikasi atau sistem serta untuk megidentifikasikan syarat-syarat informasi yang ditimbulkan dari tujuan-tujuan tersebut. Orientasi dalam fase ini adalah menyelesaikan masalah-masalah perusahaan. Meskipun teknologi informasi dan sistem bisa mengarahkan sebagian dari sistem yang diajukan, fokusnya akan selalu tetap pada upaya pencapaian tujuan-tujuan perusahaan (Kendall, 2010).

2) RAD Design Workshop: Fase ini adalah fase untuk merancang dan memperbaiki yang bisa digambarkan sebagai workshop. Penganalisis dan dan pemrogram dapat bekerja membangun dan menunjukkan representasi visual desain dan pola kerja kepada pengguna. Workshop desain ini dapat dilakukan selama beberapa hari tergantung dari pengalaman, kemampuan dan ukuran aplikasi yang akan dikembangkan. Selama workshop desain RAD, pengguna merespon prototipe yang ada dan penganalisis memperbaiki modul-modul yang dirancang berdasarkan respon pengguna. Apabila sorang pengembangnya merupakan pengembang atau pengguna yang berpengalaman, maka usaha ini dapat mendorong pengembangan sistem sampai pada tingkat terakselerasi.

3) Implementation: Pada fase implementasi ini, penganalisis bekerja dengan para pengguna secara intens selama workshop dan merancang aspek-aspek bisnis dan nonteknis perusahaan. Segera setelah aspek-aspek ini disetujui dan sistem-sistem dibangun dan disaring, sistem-sistem baru atau bagian dari sistem diujicoba dan kemudian diperkenalkan kepada organisasi.

\section{Uinfied Modelling Language (UML)}

UML merupakan suatu metode permodelan secara visual untuk sarana perancangan sistem berorientasi objek, atau definisi UML yaitu sebagai suatu bahasa yang sudah menjadi standar pada visualisasi, perancangan dan juga pendokumentasian sistem software[4]. UML juga disebut sebagai perangkat (tools) yang mendukung pengembangan suatu sistem. Saat ini UML sudah menjadi bahasa standar dalam penulisan blueprint software. Beberapa kelebihan UML yaitu dapat berguna sebagai blue print, sebab sangat lengkap dan detail dalam perancangannya yang nantinya akan diketahui informasi yang detail mengenai koding suatu program dan juga cocok untuk memodelkan sistem yang berkonsep berorientasi objek, jadi tidak hanya digunakan untuk memodelkan perangkat lunak (software) saja.

\section{LANGKAH PEMECAHAN MASAlah}

\section{Tahapan Metode Pengembangan Sistem}

\section{4) Requirements Planning}

5) RAD Design Workshop

\section{6) Implementation}

\section{E. Tools Pemodelan}

Tools pemodelan yang digunakan adalah Unified Modeling Language (UML) yang merupakan salah satu teknik pemodelan desain program berorientasi objek. UML juga menyediakan berbagai macam diagram untuk memodelkan aplikasi berorientasi objek, dan untuk menggambarkan diagram-diagram UML menggunakan tools seperti VP Online Diagrams dan Creately.

\section{F. Metode Pengumpulan dan Pengolahan Data}

Pada tahap ini dilakukan diskusi langsung dengan pihak instansi dalam hal ini yaitu pembimbing lapangan yang bertujuan untuk memperoleh kebutuhan-kebutuhan sistem dalam rangka memenuhi kebutuhan proses bisnis. Langkah yang dilakukan dalam rangka pengumpulan data ini antara lain: konsultasi proyek dan pengumpulan dokumen dan data yang dibutuhkan sebagai acuan dalam pembuatan aplikasi.

\section{Hasil dan Pembahasan}

\section{A. Requirements Planning (Perencanaan)}

Penerapan metode RAD dalam membuat aplikasi ini diawali dengan tahap perencanaan syarat dan kebutuhan website. Acuan dalam pembuatan aplikasi ini yaitu dengan menganalisa kebutuhan user, dimana user aplikasi ini terdiri dari pengunjung dan admin. Orientasi dalam fase iniadalah pemecahan masalah-masalah, berikut ini adalah hasil analisa mengenai syarat-syarat sistem, kebutuhan, data, software dan lainnya.

\section{1) Kebutuhan Fungsional}

- Halaman beranda untuk pengunjung

- Halaman informasi proyek konstruksi untuk pengunjung

- Halaman detail proyek untuk pengunjung

- Fitur keamanan untuk halaman admin 
- Halaman login untuk admin

- Halaman input data baru oleh admin

- Pengelolaan data Pembangkit oleh admin (tambah, update dan delete)

- Pengelolaan data Transmisi oleh admin (tambah, update dan delete)

- Pengelolaan data Gardu Induk oleh admin (tambah, update dan delete)

- Halaman detail proyek untuk admin

2) Resource Requirements

TABEL I. RESOURCE REQUIREMENTS

\begin{tabular}{|l|l|}
\hline Sistem Operasi & \multicolumn{1}{|c|}{ Windows 1064 bit } \\
\hline Tools \& Software & XAMPP 7.4.1 \\
& Laravel Framework 7.1.3 \\
& Composer 1.10.1 \\
& VScode \\
\hline Sumber Daya Manusia & Cleorangga Mandang \\
& David Wuisan \\
& Jeener Mandagi \\
& Dosen Pembimbing KP \\
& Pembimbing Lapangan KP \\
\hline
\end{tabular}

\section{3) Kebutuhan Data}

Untuk kebutuhan data maka dilakukan diskusi dengan pembimbing guna mengupulkan file dan data-data yang dibutuhkan dalam membuat aplikasi ini diantaranya profil perusahaan, data monitoring pra konstruksi terbaru, rencana jangka panjang PLN UIP SULBAGUT, dan lain-lain.

\section{4) Analisa Sistem}

Berdasarkan identifikasi syarat-syarat dan kebutuhan sebelumnya, untuk membuat aplikasi web yang diminta pihak PLN UIP SULBAGUT maka berikut ini poin-poin hasil analisis mengnai sistem yang akan dibuat:

- Info proyek yang dipublikasi melalui aplikasi ini hanya memuat data keseluruhan proses suatu proyek konstruksi dan tidak memuat info yang spesifik atau file-file yang mungkin tidak masyarakat perlukan.

- Data proyek-proyek disajikan dalam bentuk tabel untuk setiap jenis konstruksi, menyebabkan antarmuka layar akan terlihat sangat simple.

- Informasi realisasi suatu proyek ditampilkan dalam visualisasi yang berbentuk pie chart.

- Aplikasi web memiliki sistem keamanan admin.

- Form isian dan info proyek terkait dengan data jenis konstruksi yang dikelola yaitu data Pembangkit, Transmisi dan Gardu Induk.

\section{B. RAD Design Workshop}

Model RAD mengadopsi model waterfall tetapi dengan pembangunan dalam waktu yang lebih singkat, karena dalam RAD menerapkan pembangunan berbasis objek dan bukan prosedural maka pada fase ini ada proses-proses yang dikerjakan pada waktu yang sama, antara lain pembuatan kode program, membuat prototype-prototype, model diagram UML sistem dan melakukan testing, yang kemudian ditinjau oleh pihak instansi dalam hal ini pembimbing lapangan.

\section{1) Use-Case Diagram}

Use-Case Diagram berikut adalah gambaran grafis dari semua yang terlibat dalam sistem ini, dan interaksi-interaksi antar satu dengan lainnya yang memperkenalkan sistem ini.

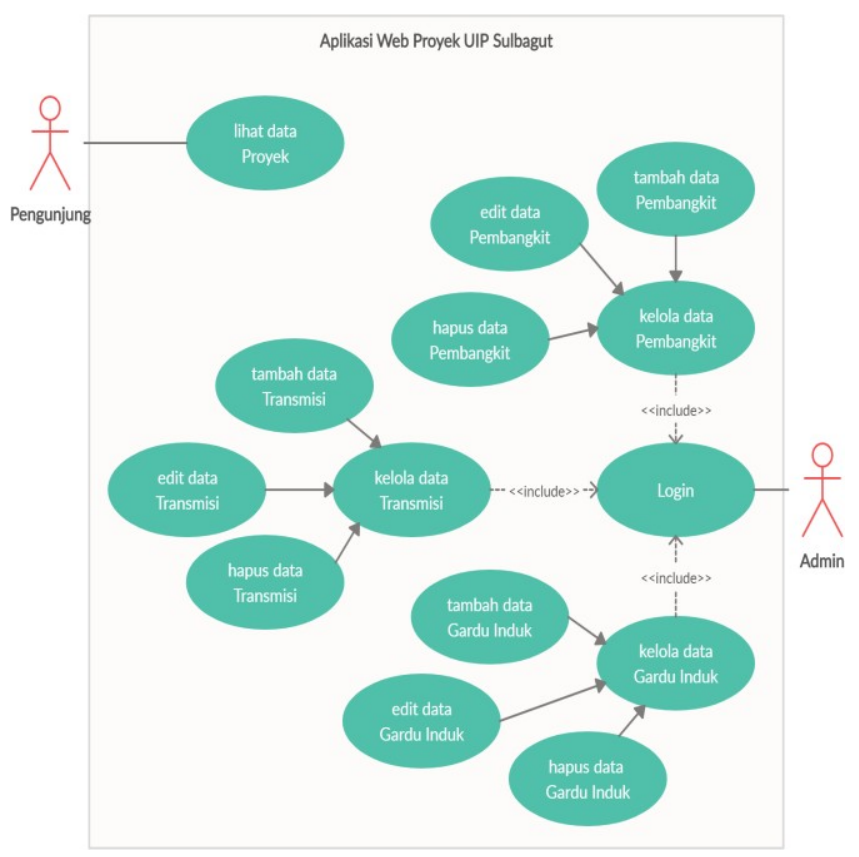

Gbr. 1 Use-Case Diagram Aplikasi Web

\section{2) Activity Diagram}

Activity Diagram berikut merupakan rancangan aliran aktivitas atau aliran kerja dalam aplikasi web proyek UIP SULBAGUT. Activity Diagram ini juga mendefinisikan atau mengelompokan aliran tampilan dari web tersebut.

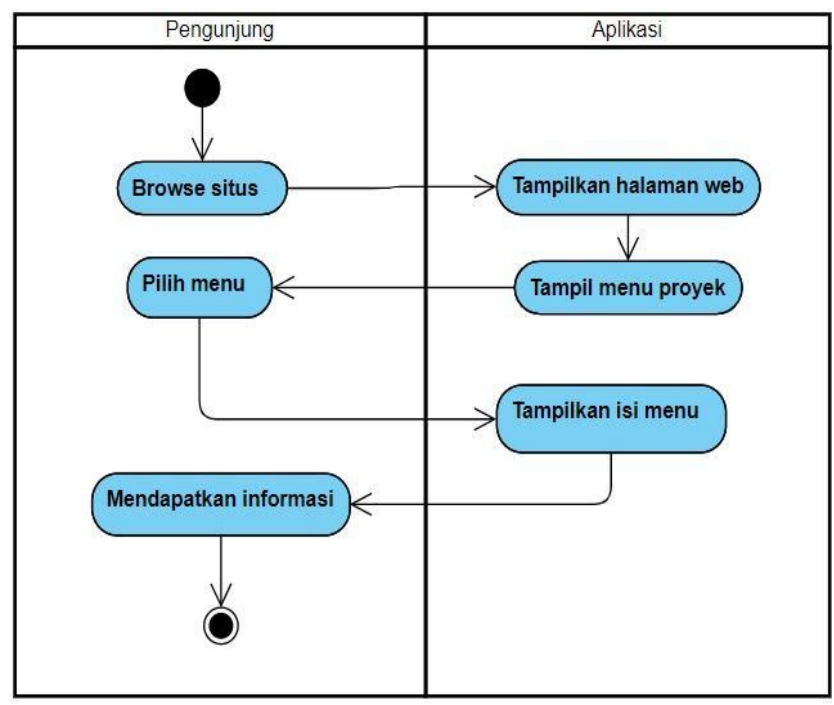

Gbr. 2 Activity Diagram Pengunjung Aplikasi 


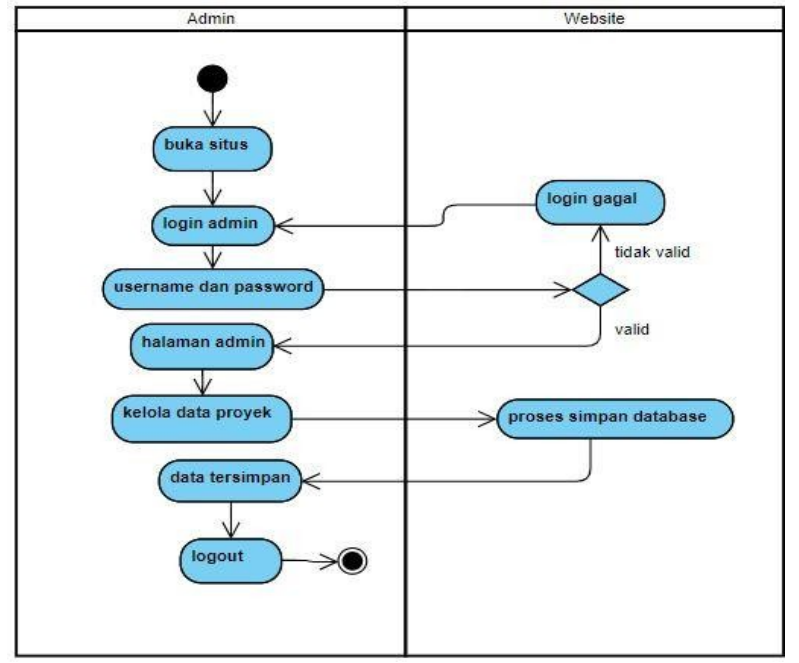

Gbr. 3 Activity Diagram Administrator Aplikasi

\section{3) Sequence Diagram}

Berikut ini adalah sequence diagram untuk mengelola data proyek yang diinginkan. Sequence diagram untuk melakukan proses pengelolaan (tambah, detail, update dan hapus) oleh admin memperlihatkan interaksi antara admin dengan sistem. Diawali dengan halaman keloa data terlebih dahulu. Admin memasukkan inputan data proyek, selanjutnya informasi mengenai proyek akan disimpan ke database.

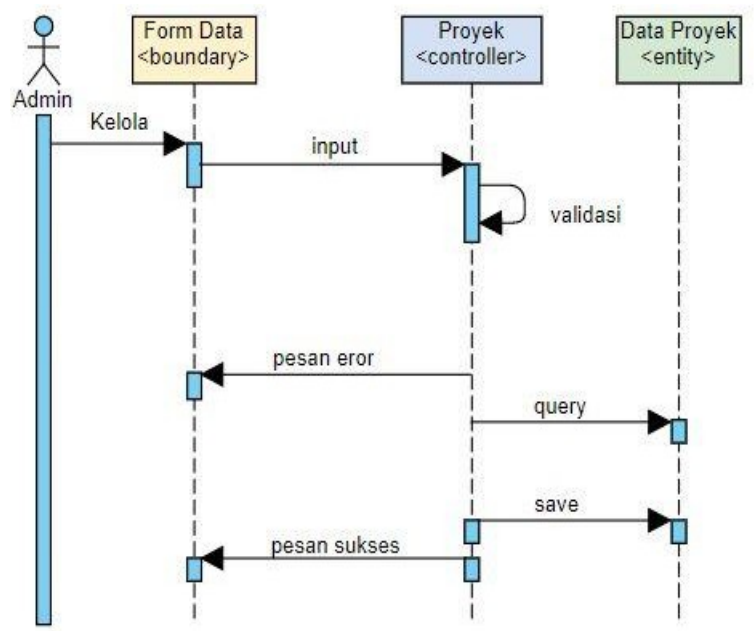

Gbr. 4 Sequence Diagram Kelola Data oleh Admin

\section{4) Uji Coba Prototype}

Berdasarkan prototype yang dibuat di fase ini, berikut ini adalah hasil pengujian aplikasi. Ada pula yang terlibat di fase ini yaitu, tim proyek, pembimbing lapangan sebagai end user aplikasi, dan juga pembimbing KP.

TABEL II. HASIL TESTING PROTOTYPE APLIKASI

\begin{tabular}{|l|l|l|}
\hline \multicolumn{1}{|c|}{ Pengujian } & \multicolumn{1}{c|}{ Hasil yang Diharapkan } & Keterangan \\
\hline $\begin{array}{l}\text { Tidak memasukkan } \\
\text { inputan saat login } \\
\text { admin }\end{array}$ & $\begin{array}{l}\text { Sistem tidak memberi akses } \\
\text { lalu menampilkan pesan error } \\
\text { validasi }\end{array}$ & Sesuai \\
\hline $\begin{array}{l}\text { Memasukkan } \\
\text { username atau } \\
\text { password yang salah }\end{array}$ & $\begin{array}{l}\text { Sistem menampilkan pesan } \\
\text { error inputan tidak tepat }\end{array}$ & Sesuai \\
\hline
\end{tabular}

\begin{tabular}{|l|l|l|}
\hline $\begin{array}{l}\text { Memasukkan } \\
\text { username dan } \\
\text { password yang } \\
\text { benar }\end{array}$ & $\begin{array}{l}\text { Sistem menjalankan } \\
\text { autentikasi dan mengarahkan } \\
\text { ke halaman admin }\end{array}$ & Sesuai \\
\hline $\begin{array}{l}\text { Mengetik langsung } \\
\text { link halaman admin }\end{array}$ & $\begin{array}{l}\text { Controller menangani proses } \\
\text { autentikasi dan langsung } \\
\text { diarahkan ke halaman login }\end{array}$ & Sesuai \\
\hline $\begin{array}{l}\text { Admin salah/tidak } \\
\text { menginput data } \\
\text { apapun pada form } \\
\text { proyek }\end{array}$ & $\begin{array}{l}\text { Form menampilkan pesan } \\
\text { validasi sesuai kesalahan }\end{array}$ & Sesuai \\
\hline $\begin{array}{l}\text { Admin menginput } \\
\text { data proyek }\end{array}$ & $\begin{array}{l}\text { Input sukses dan data benar } \\
\text { masuk ke database }\end{array}$ & Sesuai \\
\hline $\begin{array}{l}\text { Admin mengupdate } \\
\text { data proyek }\end{array}$ & $\begin{array}{l}\text { Update sukses dan data dalam } \\
\text { database benar diperbarui }\end{array}$ & Sesuai \\
\hline $\begin{array}{l}\text { Admin menghapus } \\
\text { data }\end{array}$ & $\begin{array}{l}\text { Menampilkan peringatan } \\
\text { sebelum menghapus data }\end{array}$ & Sesuai \\
\hline $\begin{array}{l}\text { Pengunjung web } \\
\text { melihat detail } \\
\text { proyek }\end{array}$ & $\begin{array}{l}\text { Menampilakan detail realisasi } \\
\text { proyek tersebut secara rinci } \\
\text { denga visualisasi chart }\end{array}$ & Sesuai \\
\hline
\end{tabular}

\section{Implementation (Implementasi)}

Pada fase imlementasi ini sudah mencakup penyempurnaan prototype yang telah dibuat pada fase sebelumnya, semua perbaikan, peningkatan dan modifikasi diterapkan pada fase ini. Berdasarkan feedback dari pembimbing tentang apa yang cocok, apa yang tidak cocok, apa yang harus dihapus dan ditambahkan, maka berikut hasil fase implementasi RAD ini.

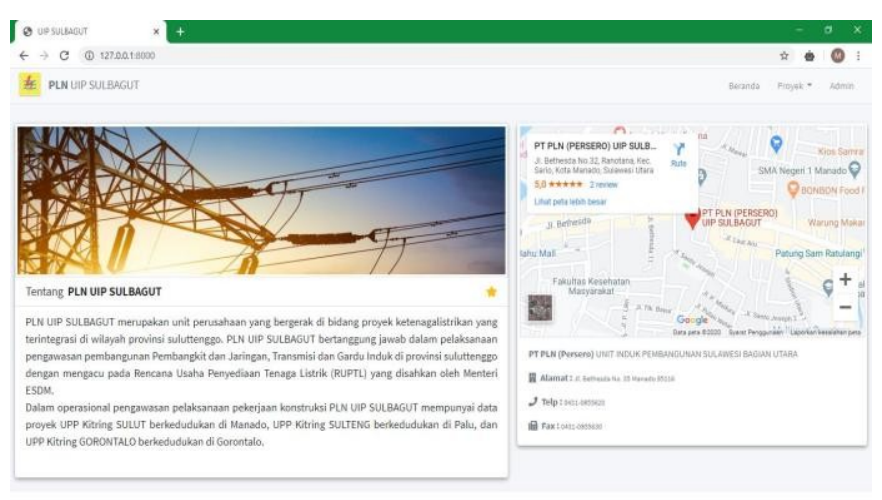

Gbr. 5 Halaman Awal Aplikasi

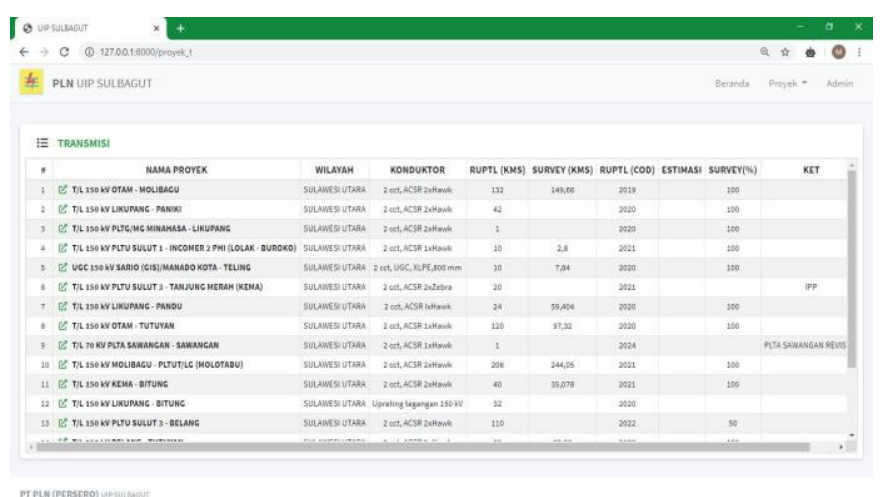

Gbr. 6 Antarmuka Halaman Proyek

Dalam mencapai realisasi suatu proyek, ada terdapat 3 jenis proses yang harus dipenuhi di setiap konstruksi, itu adalah Perijinan, Pengadaan Lahan dan Proses BID DOC \& Pengadaan (berdasarkan file monitoring pra konstruksi PLN 
Unit Induk Pembangunan Sulawesi Bagian Utara). Halaman detail proyek menunjukkan pekerjaan apa yang sudah berjalan dan sudah seperti apa progresnya.

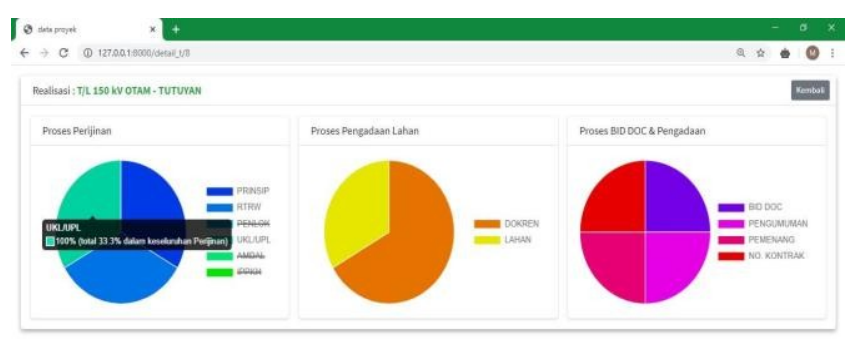

Gbr. 7 Antarmuka Detail Proyek

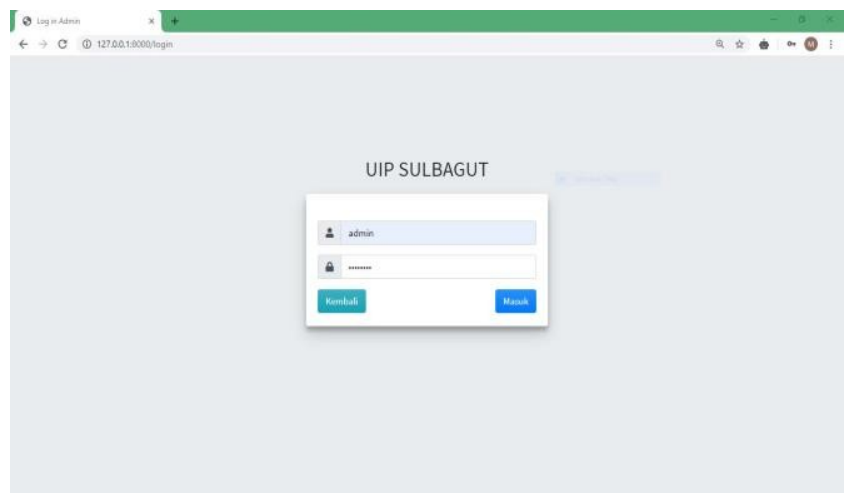

Gbr. 8 Antarmuka Login Admin

Keamanan login admin dibuat menggunakan sistem autentikasi yang disediakan framework Laravel. Jika login admin sukses maka akan diarahkan ke halaman dashboard khusus admin, di halaman ini admin dapat mengelola seluruh data proyek-proyek konstruksi yang ada, dan juga dapat menginput data proyek yang baru.

Pada sidebar halaman dashboard ini terdapat tiga jenis konstruksi yaitu Pembangkit, Transmisi dan Gardu Induk yang masing-masing memiliki struktur tabel dan form yang berbeda-beda.

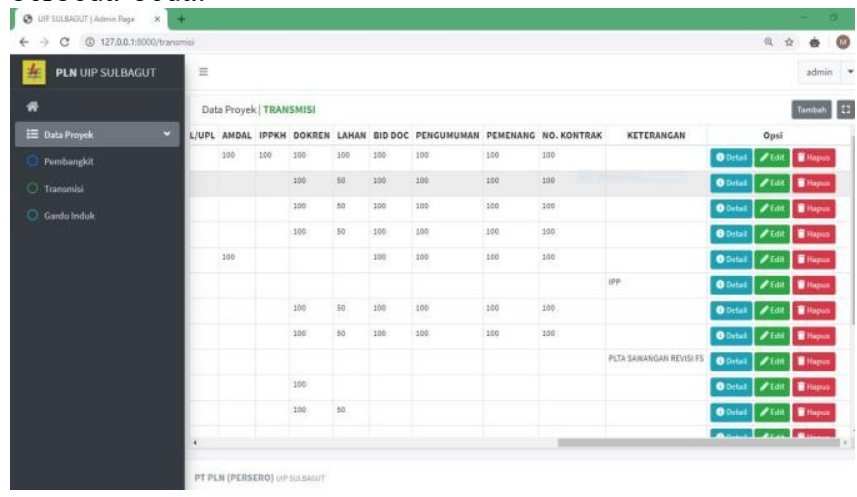

Gbr. 9 Halaman Kelola Data Proyek

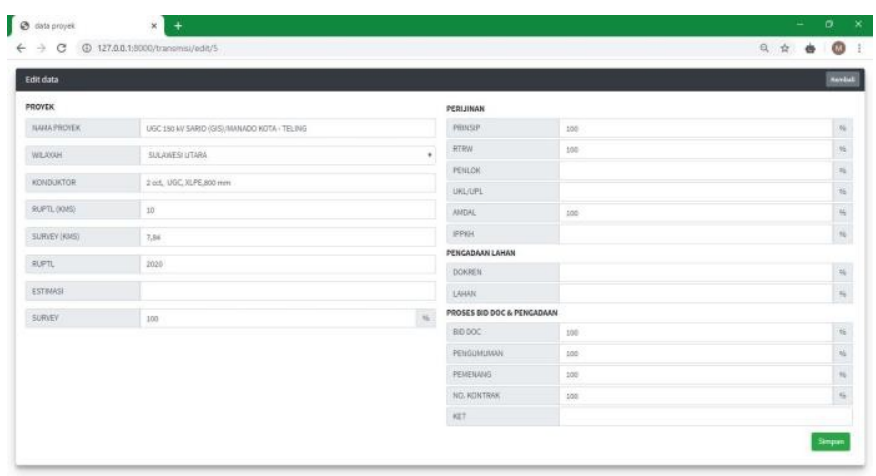

Gbr. 10 Antarmuka Form Data Proyek

Demikian antarmuka keseluruhan halaman Aplikasi Web Proyek PLN UIP Sulbagut. Halaman beranda pengunjung merupakan halaman statis yang menggambarkan mengenai PLN UIP Sulbagut.

\section{KESIMPULAN}

Berdasarkan penjelasan diatas maka kami menarik kesimpulan bahwa program aplikasi web proyek PLN UIP SULBAGUT dikembangkan atas dasar model RAD merupakan sebuah usaha untuk memberikan kemudahan bagi masyarakat untuk dapat lebih mudah mengetahui tentang UIP SULBAGUT berhubungan dengan proyekproyek apa yang sedang dikerjakan.

\section{UCAPAN TERIMA KASIH}

Kami mengucapkan banyak terima kasih kepada bapak/ibu dosen prodi Teknik Informatika UNIMA baik dosen penguji dan pembimbing, teman-teman prodi yang membantu kami penulis lewat saran dan masukan dalam menyelesaikan artikel ini.

\section{DAFTAR PUSTAKA}

[1] Jeffery L. Whitten, Lonnie D. Bentley, Kevin C. Dittman. (2004). Metode Desain \& Analisis Sistem edisi 6. Yogyakarta: Andi.

[2] Aplikasi Berbasis Web, https://www.webarq.com/id/aplikasiberbasis-web.html [diakses 08-04-2020].

[3] adikristanto.net, Rapid Application Development (RAD), http://adikristanto.net/rapid-application-development-rad/ [diakses 22-04-2020].

[4] medium.com, Andre Rahardjo, Apa itu UML? https://medium.com/@andrerahardjo/apa-itu-uml-b8f2a8f70b89 [diakses 22-04-2020].

[5] socs.binus.ac.id, Use Case Diagram, https://socs.binus.ac.id/2019/11/26/uml-diagram-use-case-diagram/ [diakses 08-04-2020].

[6] bangpahmi.com, Pengertian Activity Diagram, https://bangpahmi.com/pengertian-activity-diagram/ [diakses 2204-2020].

[7] btrbooks.com, Sequence Diagram dan Contohnya, https://btrbooks.com/pengertian-sequence-diagram/ [diakses 22-042020]. 